\title{
PEMANTAUAN KUALITAS AIR LAUT AKIBAT TUMPAHAN PASIR NIKEL DI PERAIRAN TELUK BULI, HALMAHERA
}

\section{SEA WATER QUALITY MONITORING OF NICKEL SAND SPILL CONTAMINANTS IN THE GULF OF BULI, HALMAHERA}

\author{
Asiah dan Arum Prajanti ${ }^{1}$ \\ (Diterima tanggal 23-09-2013; Disetujui tanggal 02-01-2014)
}

\begin{abstract}
ABSTRAK
Indonesia merupakan salah satu negara penghasil nikel terbesar di dunia sehingga pengelolaan hasil tambang nikel termasuk transportasi atau pengangkutan nikel dari dalam ke luar wilayah Indonesia perlu diperhatikan agar tidak menyebabkan kerugian baik materi, sosial maupun lingkungan. Pemantauan ini bertujuan untuk melihat kualitas air laut di wilayah Teluk Buli, Halmahera sebagai akibat dari tumpahan pasir nikel yang diangkut oleh kapal yang mengalami pembebanan lebih sehingga menyebabkan kapal tenggelam di perairan tersebut. Metode yang digunakan dalam pemantauan ini adalah metode survei dan pengambilan sampel secara langsung. Lokasi dan titik pemantauan berdasarkan dugaan pencemaran tumpahan pasir nikel yang menyebar sesuai pola sirkulasi arus laut, yaitu di lokasi tumpahan, beberapa meter dari sumber tumpahan dan titik kontrol. Sampel dianalisis di laboratorium Pusarpedal dengan parameter : pH, Oksigen Terlaurt (DO), Total Padatan Tersuspensi (TSS), Tembaga (Cu), Kadmium (Cd), Nikel (Ni) dan Timbal $(\mathrm{Pb})$. Hasil pemantauan air laut dibandingkan dengan nilai baku mutu perundang-undangan lingkungan hidup Keputusan Menteri Lingkungan Hidup No. 51 : 2004 tentang Baku Mutu Air Laut, lampiran III (untuk Biota Laut). Hasil pemantauan menunjukkan bahwa pada semua lokasi pemantauan nilai parameter $\mathrm{pH}$, $\mathrm{DO}, \mathrm{TSS}, \mathrm{Cu}, \mathrm{Cd}$, Ni dan $\mathrm{Pb}$ masih dibawah baku mutu yang dipersyaratkan. Sedangkan kadar $\mathrm{Zn}$ pada semua lokasi pemantauan, termasuk titik kontrol menunjukkan nilai diatas baku mutu, yaitu pada kisaran 0,062 - 0,069 $\mathrm{mg} / \mathrm{L}$. Kadar merkuri ditemukan diatas baku mutu pada tiga lokasi yang relative dekat dengan tumpahan pasir nikel tersebut dengan kisaran 0,0019-0,0081 mg/L. Sedangkan pada titik kontrol konsentrasi $\mathrm{Hg}<0,0005 \mathrm{mg} / \mathrm{L}$
\end{abstract}

Kata kunci: Pemantauan, tumpahan, pasir nikel, kualitas air laut, baku mutu air laut,

\begin{abstract}
Indonesia is one of the country's largest nickel producer in the world therefore management of mining nickel including nickel transportation from Indonesia to the outside Indonesian territory should be taken to minimize loss of material, social and environmental. Sea water quality in the Gulf of Buli-Halmahera needs to be monitored as a result of nickel sand spill from drowning a ship. Environmental sampling was done at the location that was suspected to be pollution, such as, the region of spills, the region of spread according to the currents of sea water, and the background area as control. Parameter pH, Dissolved Oxygen (DO), Total Suspended Solid (TSS), Cupper (Cu), Cadmium (Cd), Nickel (Ni) and Lead (Pb) were analyzed in a laboratory of Pusarpedal and the result compared with environmental quality standard based on the Environmental Minitry decree No. 51:2004 about Sea Water Quality Standard, attachment III (Sea Biota). The result of monitoring in all location showed that concentration level of $\mathrm{pH}, \mathrm{DO}, \mathrm{TSS}, \mathrm{Cu}, \mathrm{Cd}, \mathrm{Ni}$ and $\mathrm{Pb}$ below environmental quality standard, except $\mathrm{Zn}$ in the range 0.062 - $0.069 \mathrm{mg} / \mathrm{L}$. Concentration of Mercury found above environmental quality standard in three locations close to the sand nickel spill. Mercury concentration around the sand nickel spill were found $0.0019-0.0081 \mathrm{mg} / \mathrm{L}$, while in the control point was below $0.0005 \mathrm{mg} / \mathrm{L}$.
\end{abstract}

Keywords: Monitoring, nickel sand, spill, sea water quality, marine water quality standards,

\footnotetext{
${ }^{1}$ Pusarpedal- KLH Kawasan Puspiptek, Serpong - TangerangEmail : asiah1312@yahoo.com.
} 


\section{PENDAHULUAN}

Pertambangan pada hakekatnya merupakan upaya pengembangan sumberdaya alam mineral dan energi yang potensial untuk dimanfaatkan secara hemat dan optimal bagi kepentingan dan kemakmuran rakyat, melalui serangkaian kegiatan eksplorasi, pengusahaan dan pemanfaatan hasil tambang. Upaya tersebut bertumpu pada pendayagunaan berbagai sumberdaya, terutama sumberdaya energi dan mineral, didukung sumberdaya energi manusia yang berkualitas, penguasaan ilmu pengetahuan dan teknologi serta kemampuan manajemen.

Nikel adalah salah satu logam yang paling penting dan memiliki banyak aplikasi dalam industri. Ada banyak jenis produk nikel seperti logam halus, bubuk, spons, dan lain-lain. 62\% dari logam nikel digunakan dalam baja tahan karat, 13\% dikonsumsi sebagai superalloy dan paduan nir-besi karena sifatnya yang tahan korosi dan tahan suhu tinggi [1].

Permintaan bijih nikel di dunia pun semakin meningkat terutama untuk negara-negara Eropa dan Asia. Indonesia merupakan salah satu negara penghasil nikel terbesar. Potensi bijih nikel di Indonesia sudah diketahui sejak lama, terutama di wilayah Kabupaten Halmahera yang terletak di Provinsi Maluku Utara. Salah satu potensi yang diminati dari Kabupaten Halmahera adalah kandungan sumber daya alam diantaranya, yaitu: nikel, minyak bumi, emas, batubara, pasir besi, asbes, dan lain-lain [2]. Pengelolaan sumber daya alam dari bahan tambang sebagai salah satu komoditi unggulan devisa negara masih perlu ditata dan dikelola secara terpadu dengan memperhatikan berbagai aspek sehingga diharapkan dapat lebih optimal, misalnya dalam hal transportasi atau pengangkutan hasil tambang dari dalam ke luar wilayah Indonesia perlu diperhatikan agar tidak menyebabkan kerugian baik materi, sosial maupun lingkungan akibat dari kegiatan pertambangan tersebut.

Lautan merupakan kekayaan alam yang sering dimanfaatkan oleh manusia sebagai sumber kehidupannya. Namun di sisi lain, laut juga digunakan sebagai sarana transportasi. Transportasi laut dianggap efektif untuk pengangkutan beberapa hasil tambang, termasuk jalur ekspor impor.

Selama ini, proses pengangkutan pasir nikel, sebagai bahan dasar nikel, dari wilayah Indonesia yaitu dari perairan Teluk Buli Halmahera ke luar negeri menggunakan transportasi kapal laut. Sejak beberapa tahun yang lalu proses pengangkutan nikel telah melebihi batas berat yang diijinkan untuk sebuah kapal pengangkut. Akibatnya pada tahun 2012 terjadi kecelakaan kapal pengangkut nikel yang tenggelam di perairan tersebut. Dengan tenggelamnya kapal pengangkut pasir nikel diduga terjadi kebocoran atau tumpahan muatan kapal ke perairan Teluk Buli. Hal ini dikhawatirkan menjadi sumber pencemaran lingkungan. Bahan tambang yang terlarut dalam perairan dapat menyebabkan pencemaran terhadap kehidupan ekosistem dalam perairan tersebut. Dampak dari pencemaran yang akan terjadi pada lingkungan pesisir dan laut antara lain akan mempengaruhi kondisi terumbu karang, larva ikan, moluska, bentos serta kerugian 
sosial ekonomi berupa penurunan tangkapan ikan di wilayah melautnya nelayan tradisional.

Berdasarkan kejadian tersebut di atas, merujuk pada tupoksi Kementrian Lingkungan Hidup (KLH), maka dilakukan pemantauan terhadap kualitas air laut di sekitar tenggelamnya kapal pengangkut pasir nikel. Tujuan dilakukannya pemantauan kualitas lingkungan di perairan Teluk Buli, Halmahera Timur adalah untuk mengetahui kualitas air laut sehubungan dugaan terjadinya pencemaran lingkungan di wilayah tumpahan pasir nikel yang berasal dari kapal pengangkut pasir nikel yang karam.

\section{METODOLOGI}

Pemantauan dilakukan di wilayah perairan yang diduga terkena dampak lingkungan. Lokasi dan titik pemantauan ditentukan berdasarkan wilayah dugaan pencemaran tumpahan pasir nikel yang menyebar sesuai pola sirkulasi arus laut, yaitu di lokasi dekat tumpahan, beberapa meter dari sumber tumpahan dan titik kontrol. Pengambilan sampel tersebut berdasarkan pergerakan arus laut yang mempengaruhi karakteristik perairan.

Arus laut di kedalaman yang lebih dalam lebih banyak dipengaruhi oleh keadaan pasang surut dan sifat-sifat fisik lainnya seperti perbedaan suhu, salinitas dan tekanan [3]. Fluktuasi muka laut (pasut) merupakan hasil penjalaran dari massa air yang berpengaruh di pesisir pantai [4].

Pengambilan data primer dilakukan dengan survei lapangan, pengambilan sampel dan pengujian air laut di laboratorium serta pengolahan data hasil analisis. Pengambilan sampel dan analisis air laut dilakukan oleh laboratorium Pusarpedal - Deputi VII- KLH. Jumlah lokasi pengambilan sampel sebanyak 8 titik di perairan Teluk Buli, Halmahera Timur dengan mempertimbangkan lokasi dekat dengan tumpahan dan beberapa lokasi yang jauh dari tumpahan pasir nikel.

Pengambilan data sekunder dilakukan dengan pengumpulan data pendukung di wilayah perairan, peta, ataupun literatur. Metode pemantauan lebih menekankan pada keterwakilan sampel yang diambil dengan pengujian kuantitatif. Metode ini menjelaskan dan mendeskripsikan tentang kualitas perairan laut, seberapa besar perbedaan kadar analit yang terukur dari satu titik ke titik lainnya, dan juga nilai dari unsur yang paling dominan yang terdapat lokasi pengambilan sampel.

Paramter pengujian air laut meliputi $\mathrm{pH}$, kekeruhan, Oksigen Terlarut (DO), Total Padatan Tersuspensi (TSS), Tembaga $(\mathrm{Cu})$, Kadmium (Cd), Nikel (Ni) dan Timbal (Pb). 


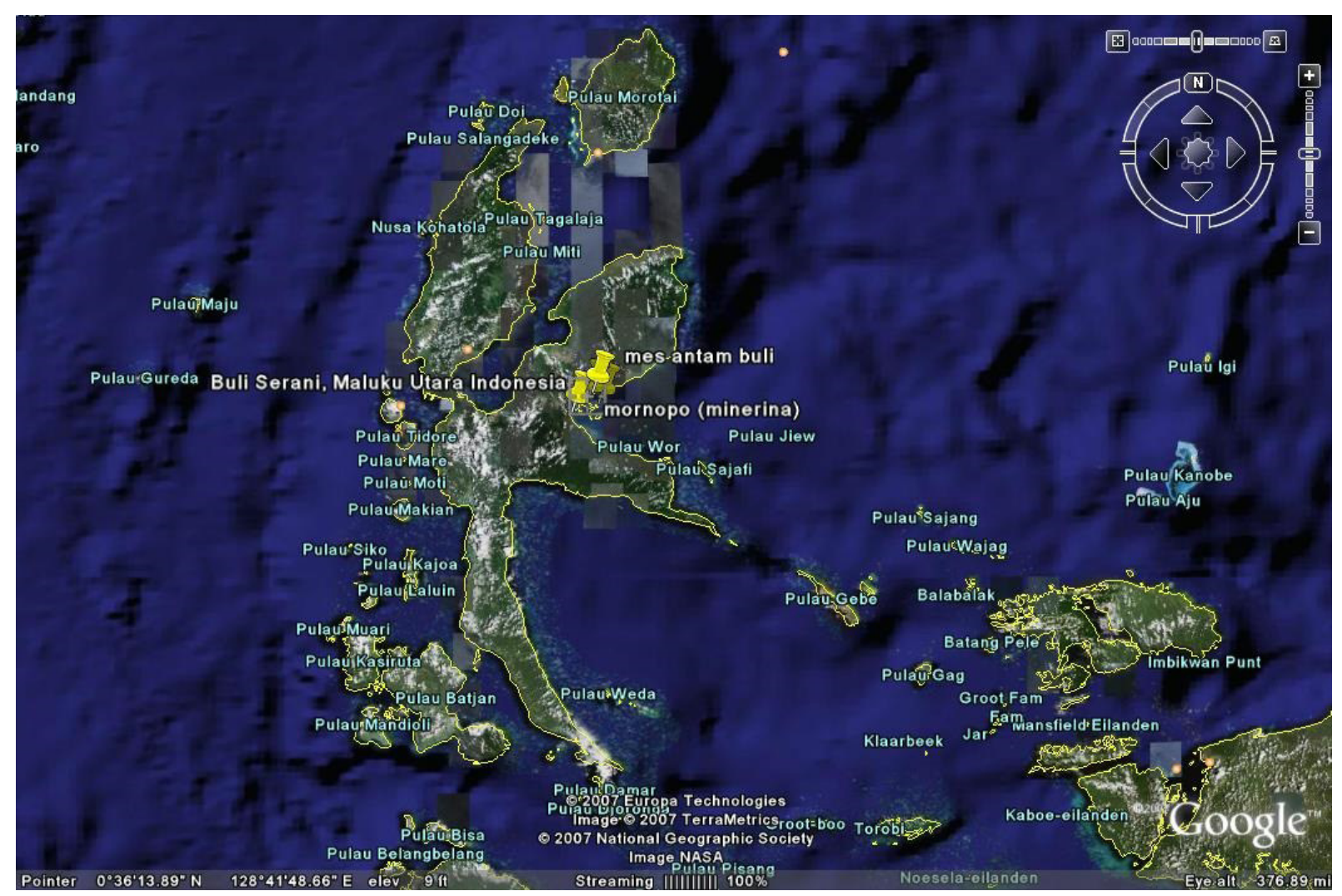

Gambar. 1 Lokasi pengambilan sampel air laut di Teluk Buli-Halmahera

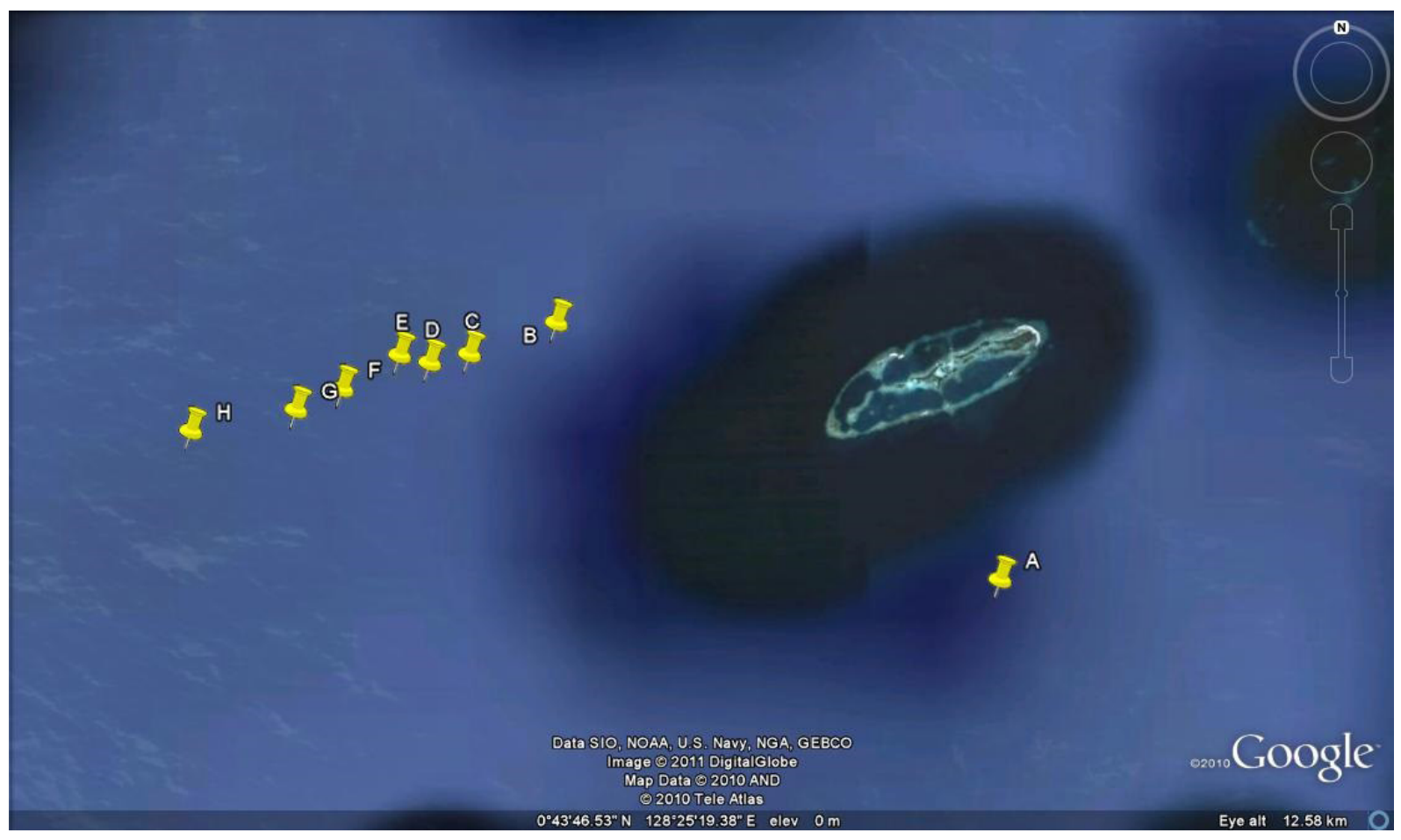

Gambar 2. Titik pengambilan sampel air dan titik kontrol (titik A) di sekitar tumpahan pasir nikel 


\section{HASIL DAN PEMBAHASAN}

Pada pemantauan ini jumlah titik pengambilan sampel adalah 8 (delapan) titik termasuk titik kontrol. Lokasi A merupakan titik kontrol dengan tujuan untuk mengetahui kualitas perairan secara alami atau tidak terkena dampak tumpahan pasir nikel. Dari hasil pengukuran $\mathrm{pH}$, DO dan TSS menunjukkan bahwa nilai untuk seluruh lokasi pengambilan sampel masih dibawah nilai baku mutu perundang-undangan lingkungan hidup
Keputusan Menteri Lingkungan Hidup No. 51 : 2004 tentang Baku Mutu Air Laut, lampiran III (Untuk Biota Laut) [5]. Secara lengkap, hasil pengujian parameter lapangan dan beberapa parameter fisik terhadap 8 (delapan) lokasi air laut yang dianalisis di Laboratorium Pusarpedal, dapat dilihat pada tabel 1. Sedangkan hasil pengujian kadar logam berat pada lokasi pemantauan dapat dilihat pada tabel 2.

Tabel 1. Hasil analisis sampel air laut di wilayah perairan Teluk Buli, Halmahera

\begin{tabular}{|c|c|c|c|c|c|c|c|c|c|c|c|c|}
\hline \multirow{2}{*}{ No } & \multirow{2}{*}{ PARAMETER } & \multirow{2}{*}{ Satuan } & \multirow{2}{*}{ METODE ANALISIS } & \multirow{2}{*}{$\begin{array}{l}\text { BAKU } \\
\text { MUTU }\end{array}$} & \multicolumn{8}{|c|}{ LOKASI SAMPLING } \\
\hline & & & & & $(\mathrm{A})$ & (B) & (C) & (D) & $(\mathrm{E})$ & $(\mathrm{F})$ & (G) & $(\mathrm{H})$ \\
\hline 1 & $\mathrm{pH}$ & & SNI 06-6989.11-2004 & $6-9$ & 8.3 & 8.3 & 8.3 & 8.3 & 8.3 & 8.32 & 8.34 & 8.25 \\
\hline 2 & Temperatur & $\left({ }^{\circ} \mathrm{C}\right)$ & SNI 06-6989.23 - 2005 & alamiah & 31.7 & 31.8 & 32.5 & 31.0 & 30.5 & 31.7 & 31.8 & 32.5 \\
\hline 3 & Oksigen Terlarut, DO & (mg/L) & SNI 06-6989.14-2004 & $>5$ & 5.65 & 5.57 & 5.49 & 5.02 & 5.41 & 5.65 & 5.57 & 5.49 \\
\hline 4 & Daya Hantar listrik, DHL & $(\mu \mathrm{S} / \mathrm{cm})$ & SNI 06-6989.1-2004 & - & 27800 & 27650 & 27650 & 27850 & 27950 & 27800 & 27650 & 27650 \\
\hline 5 & Total Padatan Terlarut, TDS & $(\mathrm{mg} / \mathrm{L})$ & SNI 06-6989.27 - 2005 & - & 18375 & 18275 & 18285 & 18390 & 18470 & 18375 & 18275 & 18285 \\
\hline 6 & Salinitas & $(\%)$ & Elektrometri & alamiah & 19.2 & 18.9 & 19 & 19.20 & 19.20 & 19.2 & 18.9 & 19.0 \\
\hline 7 & Kekeruhan & (NTU) & SNI 06-6989.25-2005 & - & 0.90 & 0.95 & 1.07 & 1.72 & 0.95 & 0.90 & 0.95 & 1.07 \\
\hline 8 & Total Padatan Tersuspensi, TSS & (mg/L) & SNI 06-6989.3-2004 & 20 & $<1$ & $<1$ & $<1$ & 1 & $<1$ & $<1$ & $<1$ & $<1$ \\
\hline
\end{tabular}

Tabel 2. Hasil analisis logam berat pada sampel air laut di wilayah perairan Teluk Buli, Halmahera.

\begin{tabular}{|c|c|c|c|c|c|c|c|c|c|c|c|c|}
\hline \multirow{2}{*}{ No } & \multirow{2}{*}{ PARAMETER } & \multirow{2}{*}{ Satuan } & \multirow{2}{*}{ METODE ANALISIS } & \multirow{2}{*}{$\begin{array}{l}\text { BAKU } \\
\text { MUTU }\end{array}$} & \multicolumn{8}{|c|}{ LOKASI SAMPLING } \\
\hline & & & & & (A) & (B) & (C) & (D) & $(\mathrm{E})$ & $(\mathrm{F})$ & $(G)$ & $(\mathrm{H})$ \\
\hline 1 & Tembaga, $\mathrm{Cu}$ & & & 0.008 & $<0.005$ & $<0.005$ & 0.0053 & 0.0054 & 0.0052 & $<0.005$ & 0.0071 & 0.0052 \\
\hline 2 & Cadmium, Cd & & USEPA modifikasi & 0.001 & $<0.0005$ & $<0.0005$ & $<0.0005$ & $<0.0005$ & $<0.0005$ & $<0.0005$ & $<0.0005$ & $<0.0005$ \\
\hline 3 & Seng, Zn & & & 0.05 & 0.069 & 0.069 & 0.066 & 0.065 & 0.064 & 0.062 & 0.064 & 0.068 \\
\hline 4 & Nikel, Ni & (mg/L) & & 0.05 & 0.0054 & $<0.005$ & $<0.005$ & 0.0053 & $<0.005$ & $<0.005$ & $<0.005$ & 0.0066 \\
\hline 5 & Timbal, $\mathrm{Pb}$ & & & 0.008 & $<0.005$ & $<0.005$ & $<0.005$ & $<0.005$ & $<0.005$ & $<0.005$ & $<0.005$ & $<0.005$ \\
\hline 6 & Merkuri , $\mathrm{Hg}$ & & SNI 19-6964.2 2003 & 0.001 & $<0.0005$ & 0.0019 & $<0.0005$ & 0.0045 & $<0.0005$ & 0.0081 & $<0.0005$ & $<0.0005$ \\
\hline
\end{tabular}

Keterangan

Lokasi titik sampling menggunakan GPS :
(A) $\mathrm{N} 0042^{\prime} 46.2^{\prime \prime}, \mathrm{E} 128026$ ' 58.2" (kontrol);
(B) N 0044' 13.6", E 128024' 27.9";
(C) N 0044' 3.0", E 128023' 58.4";
(E) N 0o 44' 2.7", E 128023' 34.7";
(D) N 0o 44' 0.1", E 128o 23' 44.9";
(G) N 0043' 44.2", E 128022' 59.5";
(F) N 0043' 51.3", E 128023' 15.2";
(H) N 0043' 37.1" , E 128022' 23.8"

(Sumber data: Laboratorium Pusarpedal-KLH) 
Nilai pH pada semua lokasi termasuk titik kontrol adalah berkisar 8 , hal ini sesuai dengan kondisi alami $\mathrm{pH}$ air laut secara alami yang cenderung basa yaitu sampai 8. Selain itu $\mathrm{pH}$ yang bersifat basa ini mungkin terpengaruh oleh sedimen dan pasir nikel yang terdapat pada daerah pemantauan yang memiliki sifat basa. Bahan yang mungkin memberikan efek basa pada lokasi tersebut adalah ore. Nickel ore adalah bijih nikel, yaitu mineral atau agregat mineral yang mengandung nikel. Bijih nikel yang dibutuhkan dalam proses penambangan ini adalah bijih yang mempunyai sifat basa, sehingga limbah cair yang dihasilkan oleh penambangan bijih nikel ini bersifat basa.

TSS pada lokasi pemantauan dan kontrol nilainya masih dibawah ambang batas sesuai peraturan perundang-undangan lingkungan hidup. Nilai TSS tersebut kecil kemungkinan karena perusahaan tambang nikel tersebut sudah melakukan pengelolaan bahan tambang sehingga kelarutan partikelnya rendah dan memiliki berat jenis yang tinggi. Dengan kondisi seperti ini maka jika pasir nikel berada pada suatu perairan atau tumpah ke perairan maka partikel akan relatif cepat mengendap di dasar perairan, sehingga menyebabkan TSS nya sangat rendah. Hal ini terbukti dengan nilai TSS di lokasi pemantauan sangat rendah yaitu $1 \mathrm{mg} / \mathrm{L}$.

Logam berat yang mencemari lingkungan, sebagian besar disebarkan melalui jalur air. Proses ini akan lebih cepat bila memasuki tubuh manusia melalui rantai makanan. Logam berat terakumulasi pada jaringan hewan dan tumbuhan, jika dikonsumsi manusia sebagai rantai makanan tertinggi maka akumulasi akan terjadi pada tubuh manusia. Sangatlah sukar untuk membersihkan lingkungan yang tercemar oleh logam berat tersebut. Oleh karena itu untuk mengontrol pencemaran lingkungan akibat logam berat, perlu dibatasi kandungan maksimum logam berat dalam suatu limbah yang diperbolehkan dibuang di badan air [6].

Kandungan logam berat $\mathrm{Zn}$ pada perairan tersebut jika dilihat dari semua lokasi termasuk kontrol, konsentrasinya sedikit melebihi baku mutu. Hal ini menunjukkan bahwa secara alami kandungan $\mathrm{Zn}$ sudah cukup tinggi. Suatu perairan atau batuan jika terdapat kandungan hasil tambang yang cukup besar, maka beberapa logam ikutannya akan tinggi juga[6]. Hampir 70\% keberadaan $\mathrm{Zn}$ di dunia dihasilkan dari penambangan. Logam Zn sebenarnya tidak toksik, tetapi dalam keadaan sebagai ion, $\mathrm{Zn}$ bebas memiliki toksisitas tinggi [7]. Seng (Zn) mempunyai dampak negatif bagi kesehatan terutama jika kadarnya sudah melebihi ambang batas. Konsumsi Zn berlebih dapat mengakibatkan defisiensi mineral lain. Intake Zn 150-450 $\mathrm{mg}$ / hari mengakibatkan penurunan kadar $\mathrm{Cu}$, pengubahan fungsi $\mathrm{Fe}$, pengurangan imunitas tubuh, serta pengurangan kadar high density lipoprotein (HDL). Satu kasus yang dilaporkan karena seseorang mengonsumsi 4 g Zn-glukonat (570 mg unsur Zn) yang setelah 30 menit berakibat mual dan muntah. Pemberian dosis tunggal sebesar 225-500 mg $\mathrm{Zn}$ bisa mengakibatkan muntah, sedangkan pemberian suplemen dengan dosis 50-150 $\mathrm{mg} /$ hari mengakibatkan sakit pada alat pencernaan. Konsumsi Zn lebih dari $50 \mathrm{mg} /$ hari selama beberapa minggu bisa menggangu ketersediaan biologi $\mathrm{Cu}$, sedangkan konsumsi $\mathrm{Zn}$ yang tinggi bisa mempengaruhi sintesis ikatan $\mathrm{Cu}$ protein atau metalotionin dalam 
usus. Konsumsi Zn berlebih akan menggangu metabolisme mineral lain, khususnya Fe dan $\mathrm{Cu}[8]$.

Konsentrasi merkuri $(\mathrm{Hg})$ di perairan pada titik B, D dan F melebihi baku mutu. Hal tersebut mungkin disebabkan lokasi tersebut cukup dekat dengan tumpahan pasir nikel. Merkuri termasuk polutan yang berbahaya bagi kesehatan manusia, sehingga keberadaannya di lingkungan harus diperhatikan. Semua bentuk merkuri baik dalam bentuk metil maupun dalam bentuk alkil yang masuk ke dalam tubuh mausia secara terus menerus akan menyebabkan kerusakan permanen pada otak, hati dan ginjal [9]. Perairan yang telah tercemar logam berat merkuri bukan hanya membahayakan komunitas biota yang hidup dalam perairan tersebut, tetapi juga akan membahayakan kesehatan manusia. Hal ini karena sifat logam berat yang persisten pada lingkungan, bersifat toksik pada konsentrasi tinggi dan cenderung terakumulasi pada biota [10]. Senyawa metil merkuri yang masuk ke dalam rantai makanan, terakumulasi pada ikan dan biota sungai.

Merkuri pada ikan dan biota perairan membahayakan kehidupan manusia karena adanya rantai makanan. Logam berat seperti $\mathrm{Hg}$ terakumulasi dalam mikro-organisme yang hidup di air (sungai, danau, laut) melalui proses metabolisme. Bahan-bahan yang mengandung logam berat yang terbuang kedalam perairan dimakan oleh mikroorganisme tersebut dan secara kimiawi terubah menjadi senyawa yang sangat berbahaya. Mikro-organisme dimakan ikan sehingga logam berat tersebut terakumulasi dalam jaringan tubuh ikan. Ikan kecil menjadi rantai makanan ikan besar dan akhirnya dikonsumsi oleh manusia. Berdasarkan penelitian, konsentrasi Merkuri yang terakumulasi dalam tubuh ikan diperkirakan 40-50 ribu kali lipat dibandingkan konsentrasi merkuri dalam air yang terkontaminasi [11].

Dari data tersebut dapat dilihat bahwa tingginya konsentrasi $\mathrm{Hg}$ dan $\mathrm{Zn}$ kemungkinan disebabkan telah terjadi peluruhan mineral logam dari tumpahan pasir nikel tersebut masuk ke dalam perairan Teluk Buli.

Konsentrasi nikel di semua lokasi masih dibawah ambang batas yang dipersyaratkan. Hal tersebut menunjukkan bahwa perusahaan tambang nikel yang bersangkutan, telah melakukan proses pengikatan nikel secara sempurna sehingga hanya sedikit yang dapat larut dalam air.

Pencemaran di perairan ini disamping berasal dari tumpahan pasir nikel, kemungkinan dari kegiatan pengoperasian kapal, adanya kebocoran bahan bakar minyak dari instalasi permesinan, pipa-pipa, tangki-tangki, tumpahan lain, atau adanya bekas cucian, yang akhirnya tercampur dalam air. Pencemaran akibat kecelakaan kapal banyak terjadi di perairan laut karena adanya tumpahantumpahan muatan minyak, muatan bahan cair beracun sebagai akibat terjadinya kecelakaan kapal seperti tubrukan, kandas, kebakaran, dan sebagainya.

Berdasarkan hasil analisis yang telah dilakukan, tumpahan pasir nikel diperairan tersebut tidak begitu mempengaruhi kualitas air, namun menyebabkan kerusakan pada ekosistem dasar laut. Dengan kapasitas pasir nikel yang cukup besar menutupi dasar lautan, maka akan menyebabkan kehidupan organisme dasar sungai akan musnah sebagian. Sembiring 
(2010) mengemukakan bahwa kemungkinan tumpahan pasir menyebar ke daerah yang lebih dangkal dan produktif secara biologis, sehingga mendatangkan lebih banyak masalah dari yang diperkirakan yaitu mengusir spesies ikan yang berpindah-pindah, menyebabkan kerusakan permanen di dasar laut, memusnahkan spesies asli, menghilangkan organisme langka dan mengurangi keanekaragaman organisme termasuk terumbu karang [12].

Dengan data pemantauan tersebut, diharapkan pengambil kebijakan di lingkungan KLH akan memberikan tindak lanjutnya secara nyata terhadap pengelolaan lingkungan hidup khususnya di perairan yang terkena dampak tersebut.

\section{SIMPULAN}

Berdasarkan hasil dan pembahasan yang telah diuraikan maka dapat diambil beberapa kesimpulan, sebagai berikut :

1. Kualitas air laut di wilayah Teluk Buli, Halmahera masih berada dalam ambang batas yang aman untuk biota laut. Hal ini berdasarkan konsentrasi pada seluruh titik pemantauan untuk parameter kualitas lingkungan $\mathrm{pH}, \mathrm{DO}$, TSS, $\mathrm{Cu}, \mathrm{Cd}$, Ni dan $\mathrm{Pb}$ menunjukkan nilai dibawah baku mutu perundangundangan lingkungan hidup Keputusan Menteri Lingkungan Hidup No. 51 : 2004 tentang Baku Mutu Air Laut, lampiran III (Untuk Biota Laut).

2. Konsentrasi Zn dan Hg pada beberapa lokasi pemantauan melebihi nilai ambang batas perundang-undangan lingkungan hidup Keputusan Menteri Lingkungan Hidup No. 51 : 2004 tentang Baku Mutu Air Laut, lampiran III (Untuk Biota Laut).

\section{UCAPAN TERIMAKASIH}

Penulis mengucapkan terimakasih kepada teman-teman bidang laboratorium rujukan dan pengujian, Pusarpedal sebagai tim yang sudah bekerjasama untuk terlaksananya kegiatan pemantauan ini.

\section{DAFTAR PUSTAKA}

1. Barkas J., (2010), Drivers and risks for nickel demand, 7th International China Nickel Conference, Shanghai

2. Anonim, Nikel Halmahera Terbesar Di Dunia. 2013. http://energitoday. com/2013/02/17/nikel-halmaheraterbesar-di-dunia. Diunduh tanggal 15 Nopember 2013

3. Ilahude, 1999. Pengantar ke Oseanologi Fisika. LIPI. Jakarta.

4. Ikawati, Yuni., dkk. 2001. Terumbu Karang Di Indonesia. Masyarakat Peduli Ilmu Pengetahuan Dan Teknologi : Jakarta.

5. Keputusan Menteri Lingkungan Hidup No. 51 : 2004 tentang Baku Mutu AirLaut, lampiran III (Untuk Biota Laut).

6. Anonim. 2010. Cara penanggulangan logam. http://www.chem-is-try.org/ artikel_kimia/biokimia/bioremoval_ metode_alternatif_untuk_ menanggulangi_pencemaran_logam berat/. Diakses tanggal September 2013.

7. Anonim, 2010.Menanggulangi Pencemaran Logam Berat. http:// www.ychi.org-ychi.org. Diunduh tanggal 18 September 2010.

8. Widowati, Wahyuet al. 2008. Efek Toksik Logam: Pencegahan dan Penanggulangan Pencemaran. Penerbit Andi. Yogyakarta. 
9. Clarkson TW, Magos L, Myers GJ. 2003. The toxicology of mercurycurrent exposures and clinical manifestations.

10. Darmono. 2010. Lingkungan Hidup dan Pencemaran. Jakarta : Penerbit Universitas Indonesia Wilayah Pesisir Dan Lautan Secara Terpadu. Jakarta : PT. Pradnya Paramita
11. Sunarto. 2006. Keanekaragaman Hayati Dan Degradasi Ekosistem Terumbu Karang. Bandung: Fakultas Ilmu Perikanan dan Kalautan, Universitas Padjajaran

12. Sembiring, Amstrong. 2010. Bahayanya Limbah Tailing Yang Dilahirkan Dari Perusahaan Tambang. http ://Kompasiana.com. Diakses pada tanggal 8 Oktober 2013. 